\title{
Inflection in history by an infinitely small being
}

\author{
Raúl Romero-Cabello ${ }^{1,2 *}, M^{a}$ Luisa Hernández Medel ${ }^{1,2,3}$, Silvia N. Martínez-Jiménez ${ }^{1,3}$, and \\ Manuelita Zavala-Pineda ${ }^{1,3}$ \\ ${ }^{1}$ Infectology Service, Hospital General de México; ${ }^{2}$ School of Medicine, Universidad Autónoma de México (UNAM); ${ }^{3}$ School of Medicine, Instituto \\ Politecnico Nacional (IPN). Mexico City, Mexico
}

I could barely believe it. I checked the time on the dashboard, it was 9:37 PM. Not even ten minutes had passed since I left, when I received a distressed call: "he is not well, he can't breathe properly". As a doctor, I have often attended to medical calls, but today was different. As I drove along the deserted avenue, I felt something oppresive in my chest, I could hear my heartbeats as hundreds of thoughts went through my mind. "I WANT EVERYTHING TO BE AS IT USED TO BE, I WANT THE TRAFFIC, THE NOISE, THE PEOPLE. I WANT LIFE BACK!" One, two or a maximum of three cars crossed my path. I heard an ambulance siren from afar. Not a single person walking on the street. The world seemed to have turned into a ghost-like scene. Not long ago, I would curse the traffic on this same route that I take. I often wished all the cars would disappear. Now my wish had come true, but... The phone call broke my thinking process. At emergency units, doctors say: "your blood oxygen level is very low, it is highly likely you have been infected with coronavirus".

It is dawn. I cough a lot and have a fever. I cannot sleep. All my body aches; I am sweating and feel faint. At the break of the day, my temperature is $38.5^{\circ} \mathrm{C}$. My body still aches. I have another shower. I do not care if I have to have a shower every hour, as long as my fever recedes. I have shortness of breath. I do not want to die! It is midday. I can still sign my name, a notary urges me. I already told my daughter I have looked for one. I cannot bear lying down. The pain in my back and chest is unbearable. I cry begging God to let me breathe. The night has fallen and I feel worse. This shortness of breath is killing me. I lie down on my stomach. I cannot stand it. I get up but cannot stand still. I stay seated the whole night, though I cannot sleep. The pain is too strong. I also have an acute earache. I am terrified. I do not want to lie down. I am sure I will not see tomorrow. I can't do it anymore! I remember when I was 13 years old and was hypothermic... There is no better definition of COVID-19 than that told by the patient's own words.

Hailing from the Far East, this microorganism of the Coronaviridae family and Coronavirinae sub-family, has a viral envelope that resembles the spikes of a crown. Coronaviruses were first identified in the 1960s and 39 species are known to date, which are distributed into four genera: alpha, beta, gamma and delta. the two first infect mammals whereas the gamma and delta genera infect birds ${ }^{1}$. The Alphacoronavirus genera associated with the common cold are HCoV-NL63, HCoV-229E. As for the Betacoronavirus genera, we have SARS-CoV (causing severe acute respiratory syndrome), MERS-CoV (causing the Middle East respiratory syndrome) and now SARS-CoV2, whose genetic material is similar to the bat coronavirus and shares almost $80 \%$ similarity to that of SARS-CoV. These are positive-sense, single-stranded RNA viruses, ranging from 80 to 220 nanometres. They pass directly to the ribosomes to produce the proteins they require in order to replicate themselves. Coronavirus has a lipid envelope stemming from the cell membranes with protein projections (spikes) to create an image reminiscent
Correspondence:

*Raúl Romero-Cabello

E-mail: romerocabello@idisalud.com
Available online: $21-07-2020$
Date of acceptance: $12-06-2020$ DOI: 10.24875/HGMX.M20000038
Rev Med Hosp Gen Mex. 2020;83(3):97-99
www.hospitalgeneral.mx

Rev Med Hosp Gen Mex. 2020;83(3):97-99
www.hospitalgeneral.mx This is an open access article under the CC BYNC-ND license (http://creativecommons.org/licenses/by-nc-nd/4.0/). 
of the solar corona, hence its name. Amongst structural and non-structural proteins, SARS-CoV2 has four structural proteins: Protein $S$, which binds to the receptor of the cell to be infected (ACE2), Protein E present in the envelope, Protein $\mathrm{M}$ in the matrix and Protein $\mathrm{N}$ in the nucleocapsid. Non-structural proteins: Orf1ab, ORF3a, ORF6, ORF7a, ORF8 and ORF10, some of which affect the blood heme group ${ }^{2,3}$.

In a nutshell, the SARS-CoV2 lifecycle consists in the virus binding to the ACE2 receptors of the host cell. Then, once the virus enters the cell, the viral RNA induces protein production, including RNA replication. Once the proteins have been produced and the RNA has been replicated, the virus is assembled, and then exits the cell by exocytosis, taking a fraction of the cell membrane as envelope. SARS-CoV2 is free and ready to attack a new cell ${ }^{2}$.

Since the early 2000s, the appearance of this microorganism in human beings, first in China and then across the world, over the course of some days, weeks and months, has generated unexpected changes in the life dynamics of individuals, families, communities, populations on a social and global scale. These include social distancing and quarantine measures, changes in lifestyle routines and many more. In addition, this has triggered a feeling of anxiety in those fearing the risk of contagion and infection, which has led to an increase in the cases of panic attacks, featuring sudden and repeated episodes of intense fear with chest pain, palpitations, shortness of breath, dizziness, distress and abdominal pain, among others ${ }^{4}$.

Healthcare actions have been greatly altered: the patient's care regarding any pathology has changed with the use of face masks, gloves and other protective equipment, which have altered doctor-patient, doctor-nurse as well as patient-nurse interactions, including assistants and every person present in doctor's offices, clinics and hospitals. As for COVID-19 patients, once patients have been consulted and hospitalized, they are bedridden. This step represents a break in the patient's social interactions with family members and friends, as no one can visit them. Communication, at its best, can be made by phone or online. In exceptional cases, severely ill patients can receive a letter written by a family member, which is read by a member of the healthcare staff on the grounds of support and compassion.

Inpatients are alone, to a point where all they can see are figures who assist them, as everyone wears personal protective equipment. Patients cannot see their faces or their skin; only face shields, masks, goggles, uniforms, etc. Every time a member of the healthcare team touches them is with plastic materials. As they cannot see the faces of doctors, nurses, technicians, stretcher-bearers, labourers, etc. patients have no idea who is treating them. As the disease progresses, patients' conditions worsen and if necessary they are sent to ICU, where all the above described is magnified ${ }^{5}$.

Patients suffer with the clinical manifestations of the disease progressively, which is increased two-fold by the physical distress and loneliness. As patients' conditions become terminal, the last words they hear are from a member of the healthcare team. These words are distorted by a protective device, not having the chance of feeling a human touch for the last time... patients die in inhuman conditions.

This dehumanizing phenomenon does not end with death. Family members will not see them again, only by photograph. No last good-byes, no final departure rites, which are common in society. This all takes an emotional, psychological and religious toll. Families and society are forever scarred ${ }^{4}$.

Profound changes have taken place in family life. Family dynamics are different during lockdown. In addition to confinement, social distancing measures mean hugging, kissing, playing and sexual relations are now restricted. This leads to emotional disorders, economic pressures, increased irritability, domestic violence, etc.

As for work, idle time and working from home brings a feeling of uncertainty, fears of losing one's job, confusion as to one's own productivity or meeting the company's expectations. These include changes in wages and possible dissatisfaction with economic demands. In turn, all this resonates in family life, generating pressure due to the difficulty of working from home, because of its many distractions and a lack of understanding by family members. Surely, there are many variants in this work activity panorama. Informal workers are affected differently, as their income is directly related to their activity; when they do not work, they do not earn money.

The world's economy, due to this pandemic, has been greatly affected with a steady decline towards a major depression, unless a formula is devised that can bring growth and development, with the engagement of all economic sectors. The stopping of work brings a paralysis of productivity, which can result in potential unemployment, lower consumption, greater poverty and food insecurity. This will inevitably cause changes in national policies and international relations, with the implicit risks that major changes 
undoubtedly bring in the short term. The International Monetary Fund has published an article that said the Coronavirus pandemic will give rise to the worst economic recession since the Great Depression. ${ }^{1}$.

At the outset of the $21^{\text {st }}$ century, in the THIRD DECADE, SARS-CoV2, an infinitely small organism, with dimensions of only a few billionths of a metre, has brought about major and profound changes to life on this Planet, to a point where history can now be divided into: Before and After the CORONAVIRUS ${ }^{1,6,7}$.

\section{Conflicts of interest}

The authors have no conflict of interest.

\section{References}

1. Cedillo-Barron L, López-Perrusquilla V, García CJ, Visosos CG. COVID-19, la enfermedad viral que se diseminó en el mundo. Rev Avance y Perspectiva. 2020;6(1): (1):1. Available from: https://avanceyperspectiva.cinvestav. $\mathrm{mx} /$ covid-19-el-virus-que-se-disemino-en-el-mundo/

2. Cui J, Li F, Shi ZL. Origin and evolution of pathogenic coronaviruses. Nat Rev Microbiol. 2019;17(3):181-92.

3. Guo YR, Cao QD, Hong ZS, Tan YY, Chen SD, Jin HJ, et al. The origin, transmission and clinical therapies on coronavirus disease 2019 (COVID-19) outbreak-an update on the status. Mil Med Res. 2020;7(1):11.

4. Ho CS, Chee CY, Ho RC. Mental health strategies to combat the psychological impact of COVID-19 beyond paranoia and panic. Ann Acad Med Singap. 2020;49(3):155-60.

5. Guan WJ, Ni ZY, Hu Y, Liang WH, Ou CQ, He JX, et al. Clinical characteristics of coronavirus disease 2019 in China. N Engl J Med.2020; 382:1708-20. doi: 10.1056/NEJMoa2002032

6. Li Q, Guan X, Wu P, Wang X, Zhou L, Tong Y, et al. Early transmission dynamics in Wuhan, China, of novel coronavirus-infected pneumonia. $\mathrm{N}$ Engl J Med. 2020;382(13):1199-1207.

7. Perlman S. Another decade another coronavirus. $\mathrm{N}$ Engl $\mathrm{J}$ Med. 2020;382(8):760-2. 